\title{
Investigation of Eco - Friendly Interlocking Masonry Units
}

\author{
M. Veerapathran ${ }^{1, a}$, S. Arnesh ${ }^{2, b^{*}}$, M. Kishore Kumar ${ }^{2, c}$, S. Rakeshwaran ${ }^{2, d}$ and \\ A. Sarankarthi ${ }^{2, e}$ \\ ${ }^{1}$ Assistant Professor (SG), Department of Civil Engineering, Dr.N.G.P Institute of Technology, \\ Coimbatore-641 048, Tamil Nadu, India \\ ${ }^{2}$ Final Year UG Students, Department of Civil Engineering, Dr.N.G.P Institute of Technology, \\ Coimbatore-641 048, Tamil Nadu, India \\ ${ }^{a}$ veerapathranm@drngpit.ac.in, ${ }^{b^{*}}$ smartsoundararnesh@gmail.com, \\ c kishorekumarm17ce@drngpit.ac.in, ${ }^{\mathrm{d}}$ rakeshwarans17ce@drngpit.ac.in, \\ e sarankarthia17ce@drngpit.ac.in
}

Keywords: Masonry Units, Interlocking Bricks, Soil, Male and Female Joints

\begin{abstract}
This project reveals about the detailed investigation of eco-friendly interlocking masonry units. Interlocking between individual units is enabled by providing grooves, male and female joint on them. Hence less mortar is required for construction of masonry units while using these interlocking bricks. Various trails and tests will be conducted on these interlocking bricks by addition of various materials such as E-wastes, coir pith and saw dust in clay soil. Hence the cost of these masonry units will be reduced. All these various mixtures are mixed at different proportions and ideal mixture are to be found then the grooves are to be altered by male and female joints. Further in addition of clay and sand, wooden powder and coir pith are to be added so that while burning of these masonry units results in good colour and more strength $35 \%$ improved strength while comparing to an A-Class brick). Optimum ratio with minimal cost and max efficiency with sustainability to the environment is recommended to the market. In the past year there was a spread of pandemic COVID 19. Precautious measures are taken to avoid the spread of this pandemic. By considering this situation a chemical is to be added in this masonry unit which will be acting as an disinfectious agent which will avoid the entry of various common viruses and bacteria like rhino viruses, salmonella. This ability of the masonry unit will last more than 24 months and beyond. And this can also be replenished after specific period of time. These masonry units have less mortar consumption (70\% less mortar consumption while comparing to an A-Class brick), more workability, disinfectious and accommodates waste materials. Hence it is considered to be eco-friendly and sustainable.
\end{abstract}

\section{Introduction}

Masonry units covered by most standards include those made from normal and light weight concretes, calcium silicate, natural stone, fired clay, interlocking blocks etc., these masonry units are one of the most important part of the building. Nowadays these masonry units cost are costlier as the quality increases. To deal with this major problem an effective idea has been proposed to achieve all the qualities of the masonry unit such as strength, workability and weight.

This project reveals the detailed investigation of general interlocking bricks and grooves made of cementatious substance and fly ash and further various trails and tests will be conducted on these interlocking bricks by addition of various materials such as plastic wastes, foundry wastes, clay soils which are used for making bricks. All these various mixtures are mixed and at different proportions and ideal mixture are to be found then the grooves are to be altered by male and female joints. Further in addition of clay sand wooden powder and coir pith are to be added so that while 
burning the burning of these masonry units are complete which gives good colour and more strength while comparing to an A-Class brick. All these ratios are to be found and tested and the mixture with minimal cost and max efficiency with sustainability to the environment is to be adopted for the market.

In the past year there was a spread of pandemic COVID 19 although there is various discussions on cure various precautious measures are taken to avoid the spread of this pandemic. By considering this situation a chemical is to be added in this masonry unit which will be acting as an disinfectious agent which will avoid the entry of various common viruses and bacteria like rhino viruses, salmonella, shigella. This ability of the masonry will last more than 24 months and beyond. And this can also be replenished after specific period of time. Since these masonry units don't need any plastering work and painting work as they come in desirable colours the disinfectious ability of the unit works more efficiently.

This investigation is to be done in the district of Coimbatore $\left(11.0168^{\circ} \mathrm{N}, 76.9558^{\circ} \mathrm{E}\right)$ in the Kongu Nadu region of the Indian state of Tamil Nadu with an area of $246.8 \mathrm{~km}^{2}$ and with Metropolitan area as $642.1 \mathrm{~km}^{2}$ which ranks as second largest district in the state of Tamil Nadu with respect to the area. Coimbatore is the Manchester of south India and is considered as one of the most developing city in Tamil Nadu. Coimbatore is one of the selected cities for the scheme of smart city development. By introduction of these masonry units the will become smarter and ecologically more efficient.

\section{Materials}

Material

Clay soil, Sawdust, E-Wastes are collected from the local regions of Coimbatore. Clay soil is sieved and graded. The Atterberg limits are checked for the soil. E-Wastes are also tested and thermoplast temperatures of the E-Wastes are also found. And saw powder is grinned finely.

\section{Mould making}

The mould is made in cast iron by providing male and female joints ate the top and bottom and also grooves are provided at the lateral parts of the mould. The base is provided with the plate and tensioned using a spring for better workability during casting.

\section{Mixture}

The clay soil is mixed with the optimum moisture content. While addition of saw dust it is mixed with the clay soil at 3:1 ratio. This mixture is followed as such in addition of E-Waste also.

\section{Methodology}

Casting

The water is mixed with the clay soil at the optimum ratio and then mixed well before the day of casting and then placed undisturbed for a day. During the day of casting it is again, mixed well then the soil is pressed with a great force into the mould and then it is pushed to the ground then the brick is removed from the mould with the help of the tensioned spring. The brick is left undisturbed for drying for minimum of 14 days at normal room temperature. Then the brick is burnt at the kiln at One thousand and two hundred (1200) degree Celsius. Similarly the same process is done while addition of E-Waste and saw dust with different ratios. 


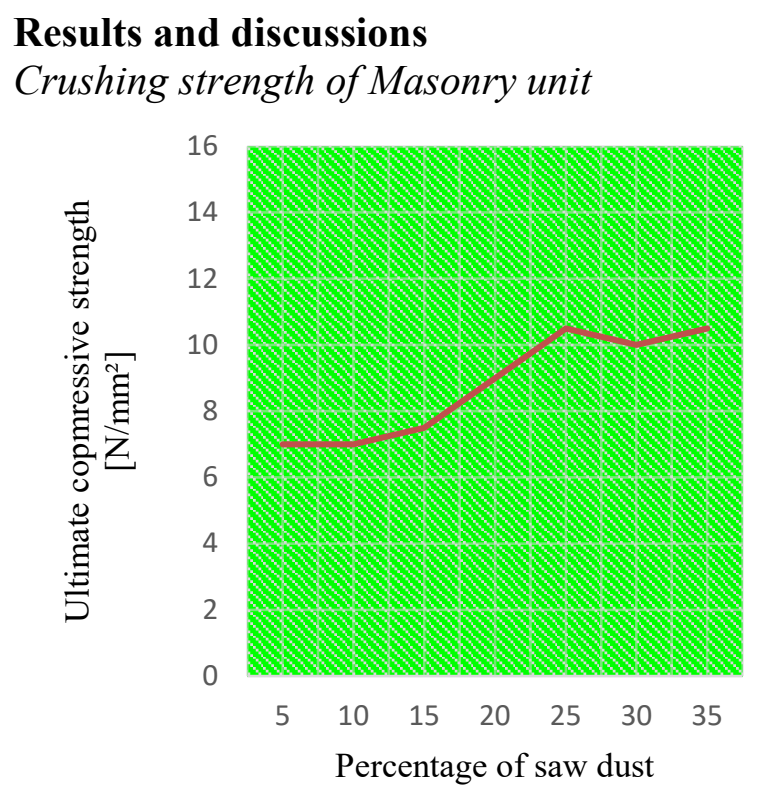

Figure 1: Compressive strength while addition of saw dust.

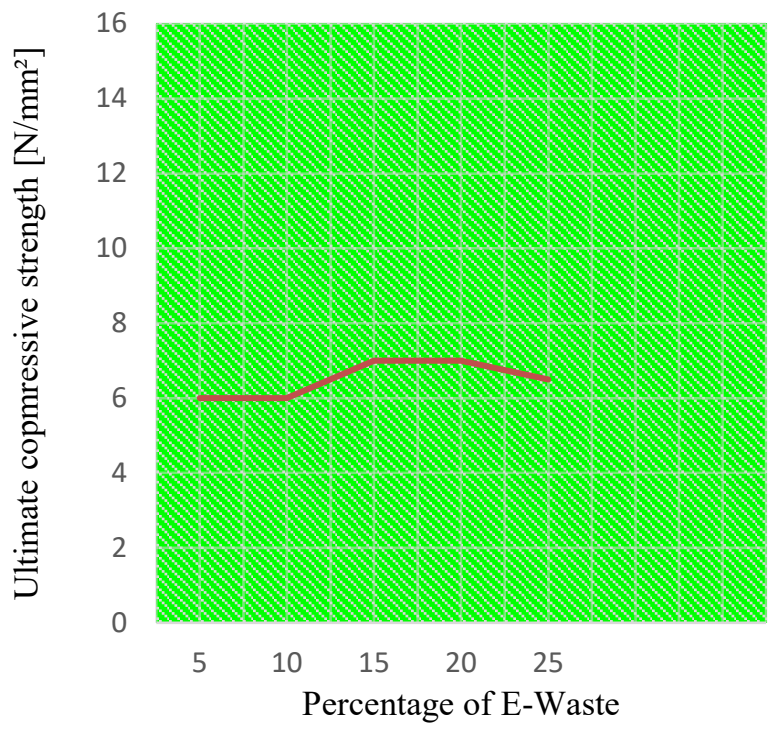

Figure 2: Compressive strength while addition of E-Waste

The crushing strength of the interlocking clay brick masonry unit is comparatively high while comparing the normal brick and it is almost equivalent to the conventional interlocking brick. The strength is more when it is tested for both individual brick as well as masonry unit. While testing in the compressive testing machine (CTM) the average compressive strength is above $7.5 \mathrm{~N} / \mathrm{mm}^{2}$ and the average compressive strength of $10.5 \mathrm{~N} / \mathrm{mm}^{2}$. Addition of saw dust by 30 percent increases the compressive strength upto 35 percent (Fig.1). Similarly by addition of E waste by 25 percent increases strength by 40 percent (Fig.2).

Water absorption of masonry unit

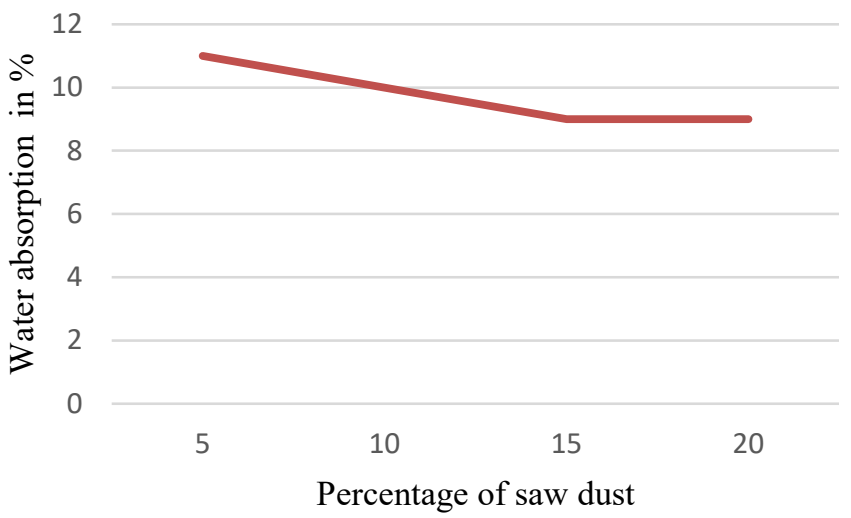

Figure 3: Water absorption while addition of saw dust

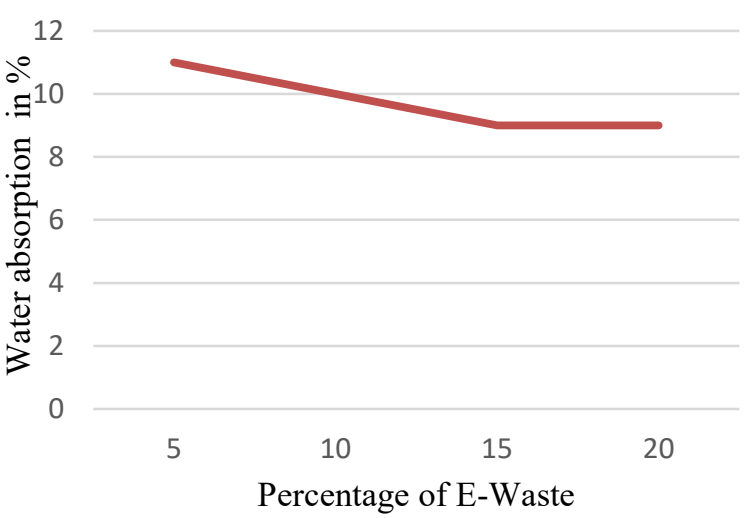

Figure 4: Water absorption while addition of E-Waste 
The water absorption of the interlocking clay brick is as similar to the normal brick and a bit more than conventional interlocking block. By addition of saw dust upto 30 percent reduces the water absorption by 3 percent (Fig.3). And by addition of E waste decreases the water absorption by 4 percent (Fig.4).

\section{Efflorescence of masonry unit}

The efflorescence of the masonry unit is less than 10 percent in bricks, interlocking clay bricks, and conventional interlocking bricks. By addition of saw dust and E wastes does not alter the efflorescence as the efflorescence depends mainly upon the soil.

\section{Hardness, Soundness, Dimension tests}

The hardness of the normal brick and interlocking clay bricks is similar. The soundness test on the interlocking clay brick gives the clear indication about the burning of brick. A well burnt clay brick gives clear bell sound. The dimensions of a normal clay is $4.5 * 2.75 * 9$ (in inches), while the conventional interlocking bricks are $16 * 6 * 5$ (in inches) and whereas clay interlocking brick are $5.5 * 3.75 * 10$ (in inches).

\section{Decrease in mortar content}

While comparing to normal clay bricks the usage of mortar for the interlocking brick masonry is less about 60 to 70 percentage (Fig.4). Conventional interlocking brick also consumes less mortar when compared to the normal clay brick.

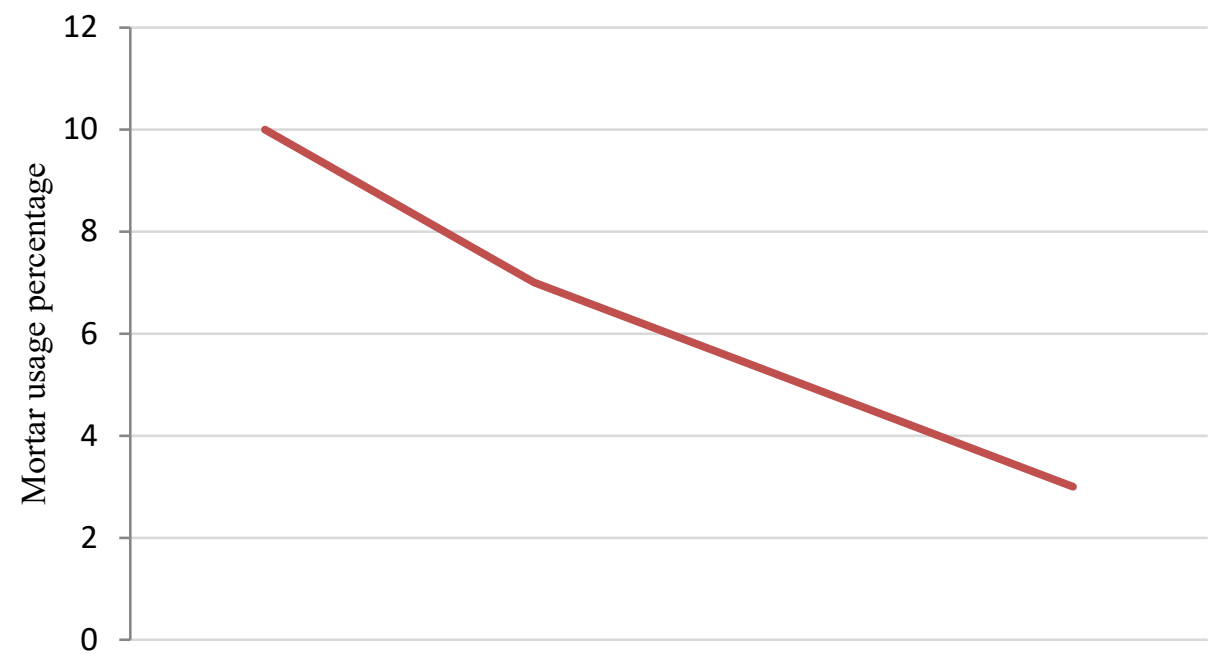

Figure 5:Decrease in mortar usage

\section{Airdal spray}

Airdal spray is sprayed over the masonry unit during the transport so that it would reduce transmission of contagious pathogens through the masonry units. A litre of the spray is used for about 500 bricks and above for the disinfection period of $24+$ months. 


\section{Conclusion}

The interlocking masonry units made up of clay soil by addition of both $E$ waste and saw dust is a new material recommended for the market as they have more workability and less labour needed. As there is increase in need for the modern technique for the field of construction. The addition of saw dust makes the masonry unit lighter and stronger while introduced into the kiln as they are completely burnt and creates pores which reduces the weight if the masonry unit. The $\mathrm{E}$ wastes are also burnt well which turns into thermoplast fills the pores thereby increasing the bonding but increase in weight. In addition to that the airdal spray is used to get rid of common bacteria to avoid contagious spread through the unit during the transport and handling of the masonry unit. And in further investigation more study should be done to get more desired results.

\section{Reference}

[1] Shivakumar. K et.al., Limestone Dust and Wood Saw As a Brick Material, International Journal of Engineering Trends and Application (IJETA) Vol.5 Issue 2 (2008).

[2] Amin Al-Fakih et.al., Development of Interlocking Masonry Bricks and its' Structural Behaviour, A Review Paper IOP Conf. Series: Earth and Environmental Science 140 (2018). https://doi.org/10.1088/1755-1315/140/1/012127

[3] Emmanuel Nana Jackson et.al.,Comparative cost analysis between interlocking bricks and sandcret blocks for residential buildings, Ghana MedCarve World of Research Vol.4 Issue 4(2018). https://doi.org/10.15406/mojce.2018.04.00120

[4] Dipakphapale et.al., Fly ash interlocking brick geo polymer concrete, International Research Journal of Engineering and Technology (IRJET) Vol.07 Issue 03 (2020).

[5] Simion Hosea Kintingu, Design of Interlocking Bricks for Enhanced Wall Construction Flexibility, Alignment Accuracy and Load Bearing, A thesis submitted to The University of Warwick, School of Engineering (2000).

[6] S.V. GiriBabu and Dr. S. Krishnaiah, Manufacturing of Eco-Friendly Brick: A Critical Review, International Journal of Computational Engineering Research (IJCER) Vol.08, Issue 02 (2018).

[7] Halima Chemani and BachirChemnai, Valorization of wood sawdust in making porous clay brick, Academic journals Vol.8, Issue 15,(2013) pp 609 - 614.

[8] Kiel Industries Germany, Airdal User guide: Ideal protection against viruses and bacteria, (2010).

[9] PeriRaghava Ravi Teja, Studies on Mechanical Properties of Brick Masonry, A thesis submitted to National Institute of Technology Rourkela, (2015). 